\title{
Recirculation on a single stage of vertical flow constructed wetland: treatment limits and operation modes
}

\author{
S. Prost-Boucle $\mathrm{a}^{\mathrm{a}, *}$, P. Molle $\mathrm{a}^{\mathrm{a}, *}$ \\ ${ }^{a}$ Cemagref, Research Unit: Freshwater Systems, Ecology and Pollution, 3bis quai Chauveau - CP 220, 69336 \\ Lyon Cedex 09, France \\ *Corresponding authors. \\ E-mail addresses: stephanie.prost-boucle@cemagref.fr (S. Prost-Boucle), pascal.molle@cemagref.fr (P. Molle)
}

\begin{abstract}
Classical French vertical flow constructed wetlands (VFCWs) plant comprises two stages of treatment which the first one nearly respects standard outlet levels. It is therefore attractive to use recirculation on a single vertical stage to reduce its footprint when outlet levels required are not too severe regards to nitrification. The present study aims at evaluating performances and limits of a full-scale experimental plant during one year and half. The monitoring has been done measuring continuously hydraulic fluxes and treatment performances in different operating conditions. Results showed good performances of the recirculating VFCW according to BOD, COD and SS parameters: mean outlet levels of 14, 73 and $19 \mathrm{mg} . \mathrm{L}^{-1}$ respectively. Besides, nitrification is strongly dependant on recirculation rate and seasons (temperature effect). Recirculation over a single stage of VFCW can improve nitrification efficiency while enhancing carbon and SS removal.
\end{abstract}

\section{Keywords}

Design, Nitrification, Performances, Recirculation, Vertical flow constructed wetland

\section{Introduction}

French Vertical Flow Constructed Wetlands (VFCWs) treat directly raw wastewater and need two stages of filters to achieve complete nitrification (Molle et al., 2005). Mean removal rates 
are 91 and $95 \%$ for COD and SS respectively, on the whole stages and $90 \%$ for nitrification. Regarding the first stage, nitrification efficiency ranges from 50 to $60 \%$ only. When outlet requirements are not too stringent, the interest of the second stage can be questioned. A recirculation loop could be a interesting way to reduce investment cost and footprint. Nevertheless, nitrification performances of the French system (raw wastewater applied on the first stage) with recirculation is unknown. Many researchers consider that nitrogen removal in VFCW may be improved by outlet effluent recirculation (Sklarz et al, 2009; He et al, 2006; Platzer, 1999) thanks to an improved water-biomass contact-time (Zhao, 2004; Sun et al, 2003), a buffer effect of inlet concentration variations (Moreno et al, 2001; White, 1995) and a greater oxygen consumption (Sun et al, 2005). However recirculation requires the setting up of electromechanical organs (recirculation pumps) leading to additional energy consumption, diminishing the environment-friendly character of the $\mathrm{CW}$ process (Stefanakis and Tsihrintzis, 2009).

As French VFCW systems are fed directly with raw wastewaters (Molle et al, 2005), recirculation experiments carried out abroad from France are not easily comparable to the recirculated French system. Recirculating VFCWsusually use a settling tank as primary treatment where the recirculated effluent is introduced (Sklarz et al, 2009; He et al, 2006; Labert et al, 1997). Moreover hydraulic and organic loads are generally much lower than the one use in the first stage of French systems without recirculation $\left(37 \mathrm{~cm} . \mathrm{d}^{-1} ; 25-30 \mathrm{gKN} . \mathrm{m}^{-2} . \mathrm{d}^{-}\right.$ ${ }^{1}$ on the filter in operation). In the same way, the organic deposit layer is generally not present while it plays an important role on ammonia adsorption and can limit oxygen fluxes. Consequently the study aims at assessing the performances a first stage of French system can achieve with a recirculation loop according to the recirculating rate and the load applied.. To this purpose a year and a half survey was carried out on a single full scale VF stage fed with raw wastewaters to avoid scaling issues.

\section{Material and methods}

\subsection{Single stage of vertical filters: design characteristics}

Experiments have been done on the Saint-Thibaud plant (Savoie, France, alt. $510 \mathrm{~m}$ ), designed for 800 p.e. (person equivalent). The plant was monitored over a 18 months period 
to test different loads and recirculation flow ratio $(\mathrm{RFR}=$ Daily recirculated effluent volume/Daily raw wastewater volume*100). Vertical reed beds were designed according to French Cemagref recommendations (Molle et al, 2005, Gravel of 2-6 mm on $80 \mathrm{~cm}$ of depth with a intermediate aeration pipe at $40 \mathrm{~cm}$ ). The first stage is divided into three filters fed by batches $(1.9 \mathrm{~cm}$ per batch). Alternation between feeding and resting periods, to prevent the filters from clogging, is of 3,5 days of feeding and one week of rest. The specific areas tested ranged from 1.1 to $1.6 \mathrm{~m}^{2}$.p.e. ${ }^{-1}$, depending on the load applied..

\subsection{Plant monitoring}

\subsubsection{Hydraulic and RFR}

Inlet, outlet and recirulating flows were continuously measured (every minute) by acquisition of pump functioning time. The RFR tested were 50, 100 or $200 \%$ over four periods as detailed in Table 1.

\subsubsection{Treatment performances}

Treatment efficiency was assessed by 24-h flow composite samples spread out throughout the studying periods. Performances of the plant were measured for SS, COD, $\mathrm{BOD}_{5}, \mathrm{KN}$, $\mathrm{NH}_{4}-\mathrm{N}, \mathrm{NO}_{3}-\mathrm{N}, \mathrm{NO}_{2}-\mathrm{N}$ removal, according to French standard methods (AFNOR, 2008). Moreover, $\mathrm{NH}_{4}-\mathrm{N}, \mathrm{NO}_{3}-\mathrm{N}$, conductivity and $\mathrm{pH}$ were assessed into each 1-h sample in order to evaluate nitrification efficiency according to load variation within the day. Furthermore, online optical analyzers (Royce) monitored inlet and outlet SS concentrations. Gaseous $\mathrm{O}_{2}$ and $\mathrm{CO}_{2}$ concentrations were regularly performed (by a DräggerSensor $\mathrm{X}$ am 7000@ gas analyzer) in order to estimate the aerobic conditions inside the porous media for several depths. Results are expressed in percent of the air phase $( \pm 0.2 \%)$.

\section{Results and discussion}

\subsection{Removal performances}


Mean values of global removal rates and concentrations are synthesized in Tables 1. Wastewater characteristics variations are normal for small communities $\left(\mathrm{COD} / \mathrm{BOD}_{5}\right.$ ratio of 2.8 \pm 0.5 ). Treatment yields achieved by the filter (called "local") were distinguished between those obtained by the treatment plant (called "global"). The later takes into account the inlet dilution impact of recirculation while "Local performances" concern the filter removal rates only. Local and global removal yields are over $80 \%$ for SS, COD and BOD except during the starting phase. Despite these good performances, high concentrations are sometimes observed at the output (see Table 1). They are caused by high input raw concentrations. For example, COD parameter varies up to $1500 \mathrm{mgCOD} . \mathrm{L}^{-1}$. It is easy to notice the failure to respect outlet quality objectives in phases 3 and 4 when the filter is strongly overloaded. In phase 4 , the system recovers with difficulty after winter overloads, even with a low RFR and the return of warmer temperatures. On the contrary, even in winter (phase 2), treatment performances are excellent when the nominal loads are close to $300 \mathrm{gCOD} \cdot \mathrm{m}^{-2}$ and $0.37 \mathrm{~m} \cdot \mathrm{d}^{-1}$.

\subsubsection{SS}

SS are over-all well filtered whatever season, hydraulic or organic loads conditions. Due to recirculation, SS loads overcome $150 \mathrm{gSS} . \mathrm{m}^{-2} \cdot \mathrm{d}^{-1}$, but filtering performances stay quite stable with global yields of about $90 \%$. When SS loads exceed $250 \mathrm{~g} \cdot \mathrm{m}^{-2} \cdot \mathrm{d}^{-1}$ and hydraulic loads are high, performances tend to fail in winter. Online SS measurements allowed to state that buffer effect is insignificant for SS; outlet SS concentrations vary with inlet concentration.

\subsubsection{BOD5 and COD}

Good and stable global removal rates are observed for COD (Table 1) and $\mathrm{BOD}_{5}$, above 80 and $85 \%$, respectively. This is apparently independent on water temperature: measurements carried out in summer and winter show similar efficiency regardless of the temperature, even during periods of night frost. Performances on local COD removal are equivalent to these obtained by a first VF stage without recirculation (Molle et al, 2005). Up to $450 \mathrm{gCOD} \cdot \mathrm{m}^{-2} \cdot \mathrm{d}^{-1}$, no impact of recirculation is noted on the filter treatment efficiency as COD performances are maintained above $90 \%$. A slight negative impact is pointed out for high loads such as $600 \mathrm{gCOD} \cdot \mathrm{m}^{-2} \cdot \mathrm{d}^{-1}$ : removal rates dropped to $82 \%$. Global performances are improved by recirculation diluting effect. Nevertheless, a single stage filters with recirculation 
can show performance limitations, preventing the respect of the outlet quality level. Despite global yields above $90 \%$, this is observed when raw wastewaters are strongly concentrated.

\subsection{Nitrification removal capabilities}

\subsubsection{4-h flow composite sample}

Local nitrification performances of the filter are consistent to those observed on a classical system (Molle et al., 2008). This is observed even for high hydraulic loads (linked to high RFR) and for nitrogen loads up to $45 \mathrm{gKN} \cdot \mathrm{m}^{-2} \cdot \mathrm{d}^{-1}$ (i.e. $35 \mathrm{gNH}_{4}-\mathrm{N} \cdot \mathrm{m}^{-2} \cdot \mathrm{d}^{-1}$ ): 50 to $60 \% \mathrm{KN}$ removal. Because of the variations of operating conditions, sometimes simultaneously, no clear tendency between performances and operating parameters is obtained. Data processing can however provide some interesting conclusions:

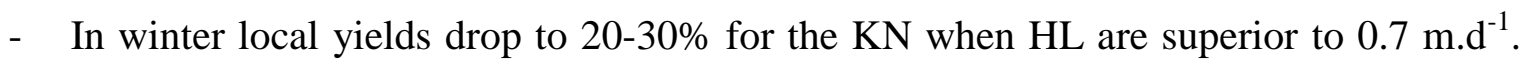
Such HL seem to be the limit to maintain nitrification for low temperatures (water temperature $<10^{\circ} \mathrm{C}$ ). Indeed, increasing RFR impacts the oxygen renewal because of reduced drainage times between each batch. In fact, after one week of rest, oxygen level is still under $5 \%$ just after phase 3 ( $\mathrm{KN}$ yields $<50 \%$ ) while it is above $15 \%$ in phase 4 (KN yields $>65 \%)$.

- On the contrary, dilution effect induced by recirculation is of importance in order to reach low outlet levels. Global nitrification performances of approximately $70 \%$ over a single stage can be expected by this way. Nevertheless the outlet level it is possible to respect appears to be of $30 \mathrm{mgKN} . \mathrm{L}^{-1}$.

\subsubsection{Nitrification variations.}

Incoming and treated nitrogen loads measured each $1 \mathrm{~h}$ step know a nitrification efficiency variability because of operating conditions variations (temperature, RFR, loads, seasons, inlet concentrations...). As can be seen in Fig. 1, outlet $\mathrm{NH}_{4}-\mathrm{N}$ concentrations are quasi-constant while inlet concentrations vary. This smoothing effect of outlet levels has been observed for each sampling periods. It takes place thanks to the filter's water storage. Once reaching a stable saturation state (4-5 hours after the beginning of a feeding period), and analyzing only nitrification rate for inlet concentrations higher than $40 \mathrm{mgNH}_{4}-\mathrm{N} . \mathrm{L}^{-1}$, we notice a good correlation of nitrification efficiency with the load applied (Fig. 2). In these conditions (100\% 
RFR), schedule nitrification rates are of $61 \%$ by mean. But this relation is not valid when input loads vary quickly (linear model in Fig 1). Then the buffer effect helps to smooth outlet levels, which is positive for high input concentrations but negative otherwise. To better represent nitrification rate with inlet concentration variations, we plotted nitrification yields according to N-NH4 inlet concentration (ex. for June 2009, Fig. 3a).

\subsection{Design and limits}

To give some design guideline on French VFCW with recirculation we fit a first order equation inspired from biodegradability models (Gillot and Choubert, 2010):

$$
\text { Removal yield }=\operatorname{Rmax} *\left(1-\operatorname{Exp}^{\left(-\mathrm{k}^{*}(\mathrm{Cin}-\mathrm{Cmin})\right)}\right)
$$

where Rmax represents the maximum of nitrification removal rate (\%), $\mathrm{k}$ is a constant, $\mathrm{Cin}$ and $\mathrm{Cmin}$ the inlet and outlet minimum $\mathrm{NH}_{4}-\mathrm{N}$ concentration respectively. The model was safely adjusted and validated for each sample date, in the aim to take into account the removal rate variability. Cmin was of $25 \mathrm{mgNH}_{4}-\mathrm{N} . \mathrm{L}^{-1}$ and $\mathrm{k}$ value was fitted to the data (Fig 3a). This model is used to give some trends of outlet ammonium concentrations according to design and recirculation rates. To maintain satisfactory nitrification a compromise has to be done between improving recirculation rate (dilution effect) and not overpass hydraulic load greater than $0.7 \mathrm{~m} \cdot \mathrm{d}^{-1}$ on the filter in operation (lack of oxygen for nitrification). The impact of different design and RFR configurations on nitrification efficiency at nominal load (150 L.p.e. ${ }^{-1} \cdot \mathrm{d}^{-1} ; 12 \mathrm{gKN}$.p.e. $\left.{ }^{-1} \cdot \mathrm{d}^{-1}\right)$ is presented in fig $3 \mathrm{~b}$, assuming:

- an inlet flow and $\mathrm{NH}_{4}-\mathrm{N}$ concentration variations as observed on Saint-Thibaud plant (see Fig. 3b),

- theoretical nitrification efficiency based on efficiency measured on Saint-Thibaud plant (see Fig. 3a).

It appears that recirculation on a single vertical flow filter can not deliver a complete nitrification. If RFR has an impact on $\mathrm{NH}_{4}-\mathrm{N}$ outlet level, it can be state that using surface of 1.0-1.2 $\mathrm{m}^{2}$.p.e. ${ }^{-1}$ is too small to respect $30 \mathrm{mg} \mathrm{KN} . \mathrm{L}^{-1}$ (Fig. 3b). It is preferable to use total surface of about $1.5 \mathrm{~m}^{2} \cdot \mathrm{p} . \mathrm{e}^{-1}$ and $100 \%$ of RFR. 


\section{Recommendations and conclusion}

Considering a total surface of 1.1 to $1.6 \mathrm{~m}^{2}$.p.e. ${ }^{-1}$ on this studied recirculated single stage VFCW, global removal yields are over $80 \%$ for SS, BOD and COD, similar to those obtained on a classical French system (two successive stages VFCWs for a total surface of $2 \mathrm{~m}^{2}$.p.e. ${ }^{-1}$. Dilution effect induced by recirculation is of importance to reach low outlet levels. Filtering performances stay quite stable with global yields about $90 \%$ even when SS loads exceed 250 g. $\mathrm{m}^{-2} \cdot \mathrm{d}^{-1}$. Results suggest that high loading rates up to $600 \mathrm{gCOD} \cdot \mathrm{m}^{-2} \cdot \mathrm{d}^{-1}$ can be treated by the system without drastically affect COD performances. Despite good and stable performances over the course of a year, the outlet concentrations sometimes exceed quality levels due to particularly high raw wastewater concentrations (e.g., BOD BO $_{5} 350 \mathrm{mg} . \mathrm{L}^{-1}$ ). In such condition, a final and simple treatment step can be implemented to retain outlet SS (e.g. vegetative filter strip, vegetated ditches).

The system shows nitrification limitation when HL are superior to $0.7 \mathrm{~m} . \mathrm{d}^{-1}$, particularly in winter. The minimum outlet level on which it is possible to achieve appears to be of $30 \mathrm{mgKN} . \mathrm{L}^{-1}$ according to the following design recommendations i) a total surface (for the 3 parallel VF filters) of $1.5 \mathrm{~m}^{2} /$ p.e., ii) a $100 \%$ RFR, iii) feeding/resting periods of $3.5 / 7$ days respectively. Recircluation allows to smooth outlet levels which is positive while input concentrations vary significantly in the course of the day.

\section{Acknowledgements}

The authors would like to thank the Rhône Méditerranée \& Corse water authority and Onema for their financial support, and Saint-Thibaud de Couz community for its availability.

\section{References}

AFNOR, 2008. Qualité de l'Eau. ISBN: 978-2-12-179081-7.

Gillot S., Choubert J.-M., 2010. Biodegradable organic matter in domestic wastewaters: comparison of selected fractionation techniques. Water Sci. Technol. 62 (3), 630-639. 
He, L.S., Liu, H.L., Xi, B.D., Zhu, Y.B., 2006. Effect of effluent recirculation in vertical flow constructed wetland on treatment efficiency of livestock wastewater. Water Sci. Technol. 54 (11-12), 137-146.

Labert, J., Perfler, R., Haberl, R., 1997. Two strategies for advanced nitrogen elimination in vertical flow constructed wetlands. Water Sci. Technol. 35 (5), 71-77.

Molle, P., Liénard, A., Boutin, C., Merlin, G., Iwema, A., 2005. How to treat raw sewage with constructed wetlands: an overview of the French systems. Water Sci. Technol. 51 (9), $11-21$.

Molle, P., Prost-Boucle, S., Liénard, A., 2008. Potential of total nitrogen removal by combining vertical flow and horizontal flow constructed wetlands: a full scale experiment study. Ecol. Eng. 34 (1), 23-29.

Moreno, C., Farahbakhshazad, N., Morrison, G.M., 2001. Ammonia removal from oil refinery effluent in vertical upflow macrophyte column systems. Water, Air, and Soil Pollution $135,237-247$.

Platzer, C., 1999. Design recommendations for subsurface flow constructed wetlands for nitrification and denitrification. Water Sci. Technol. 40 (3), 257-263.

Prochaska, C.A., Zouboulis A.I., Eskridge K.M., 2007. Performance of pilot-scale verticalflow constructed wetlands, as affected by season, substrate, hydraulic load and frequency of application of simulated urban sewage. Ecol. Eng. 31, 57-66.

Sklarz, M.Y., Gross, A., Yakirevich, A., Soares, M.I.M., 2009. A recirculating vertical flow constructed wetland for the treatment of domestic wastewater. Desalination 246, 617624 .

Stefanakis, A.I., Tsihrintzis, V.A., 2009. Effect of outlet water level raising and effluent recirculation on removal efficiency of pilot-scale, horizontal subsurface flow constructed wetlands. Desalination 248, 961-976

Sun, G., Gray, K.R., Biddlestone, A.J., Allen, S.J., Cooper, D.J., 2003. Effect of effluent recirculation on the performance of a reed bed system treating agricultural wastewater. Process Biochem. 39, 351-357.

Sun, G., Zhao, Y., Allen, S., 2005. Enhanced removal of organic matter and ammoniacalnitrogen in a column experiment of tidal flow constructed wetland system. Journal of Biotechnol. 115, 189-197. 
Vymazal, J., 2005. Horizontal sub-surface flow and hybrid constructed wetland systems for wastewater treatment. Ecol. Eng. 25, 478-490.

White, K.D., 1995. Enhancement of nitrogen removal in subsurface flow constructed wetlands employing a 2-stage configuration, an unsaturated zone, and recirculation. Water Sci. Technol. 32 (3), 59-67.

Zhao, Y.Q., Sun, G., Allen, S.J., 2004. Purification capacity of a highly loaded laboratory scale tidal flow reed bed system with effluent recirculation. Sci. of the Total Envir. $330,1-8$.

Table 1. Tested operation modes, concentrations and removal rates

\begin{tabular}{|c|c|c|c|c|c|c|c|c|c|c|c|c|}
\hline & \multicolumn{3}{|c|}{ Phase 1} & \multicolumn{3}{|c|}{ Phase 2} & \multirow{2}{*}{\multicolumn{3}{|c|}{$\frac{\text { Phase } 3}{100 \%}$}} & \multicolumn{3}{|c|}{ Phase 4} \\
\hline RFR (\%) & \multicolumn{3}{|c|}{$200 \%$} & \multicolumn{3}{|c|}{$100 \%$} & & & & \multicolumn{3}{|c|}{$50 \%$} \\
\hline $\begin{array}{l}\text { Organic load } \\
\left(\text { gCOD } \cdot \mathrm{m}^{-2} \cdot \mathrm{d}^{-1}\right)^{*}\end{array}$ & \multicolumn{3}{|c|}{250} & \multicolumn{3}{|c|}{300} & \multicolumn{3}{|c|}{670} & \multicolumn{3}{|c|}{350} \\
\hline $\begin{array}{l}\text { KN load } \\
\left(\mathrm{gKN} \cdot \mathrm{m}^{-2} \cdot \mathrm{d}^{-1}\right)^{*}\end{array}$ & \multicolumn{3}{|c|}{ - } & \multicolumn{3}{|c|}{25} & \multicolumn{3}{|c|}{60} & \multicolumn{3}{|c|}{40} \\
\hline $\mathrm{HL}\left(\mathrm{m} \cdot \mathrm{d}^{-1}\right)$ & \multicolumn{3}{|c|}{0.50} & \multirow{2}{*}{\multicolumn{3}{|c|}{$\begin{array}{c}0.40 \\
\text { autumn-winter, } \\
2008\end{array}$}} & \multirow{2}{*}{\multicolumn{3}{|c|}{$\begin{array}{c}0.75 \\
\text { winter -spring, } \\
2009\end{array}$}} & \multicolumn{3}{|c|}{0.40} \\
\hline Season & \multicolumn{3}{|c|}{ all, 2004-2008 } & & & & & & & \multicolumn{3}{|c|}{ summer, 2009} \\
\hline Water temp. $\left({ }^{\circ} \mathrm{C}\right)$ & \multicolumn{3}{|c|}{-} & \multicolumn{3}{|c|}{ 9-18 } & \multicolumn{3}{|c|}{$5-15$} & & $15-20$ & \\
\hline $\begin{array}{l}\text { 24-h flow composite } \\
\text { samples (number) }\end{array}$ & punctu & al sa & mples & \multicolumn{3}{|c|}{4} & \multicolumn{3}{|c|}{4} & \multicolumn{3}{|c|}{4} \\
\hline Conc. (mg.L $\mathrm{L}^{-1}$ ) & raw & in & out & raw & in & out & raw & in & out & raw & in & out \\
\hline SS & $\begin{array}{c}480 \\
\pm 173\end{array}$ & - & $\begin{array}{c}41 \\
\pm 31\end{array}$ & $\begin{array}{l}493 \\
\pm 96\end{array}$ & $\begin{array}{c}383 \\
\pm 162\end{array}$ & $\begin{array}{l}19 \\
\pm 2\end{array}$ & $\begin{array}{l}363 \\
\pm 41\end{array}$ & $\begin{array}{l}304 \\
\pm 52\end{array}$ & $\begin{array}{l}42 \\
\pm 4\end{array}$ & $\begin{array}{r}769 \\
\pm 148\end{array}$ & $\begin{array}{l}430 \\
\pm 80\end{array}$ & $\begin{array}{l}42 \\
\pm 4\end{array}$ \\
\hline COD & $\begin{array}{l}1246 \\
\pm 309\end{array}$ & - & $\begin{array}{l}125 \\
\pm 64\end{array}$ & $\begin{array}{c}942 \\
\pm 136\end{array}$ & $\begin{array}{c}736 \\
\pm 240\end{array}$ & $\begin{array}{l}73 \\
\pm 7\end{array}$ & $\begin{array}{c}706 \\
\pm 166\end{array}$ & $\begin{array}{r}708 \\
\pm 132\end{array}$ & $\begin{array}{l}143 \\
\pm 20\end{array}$ & $\begin{array}{l}1465 \\
\pm 173\end{array}$ & $\begin{array}{c}861 \\
\pm 127\end{array}$ & $\begin{array}{l}146 \\
\pm 11\end{array}$ \\
\hline $\mathrm{BOD}_{5}$ & $\begin{array}{c}681 \\
\pm 269\end{array}$ & - & $\begin{array}{c}37 \\
\pm 22\end{array}$ & 325 & 215 & 14 & 329 & 237 & 33 & $\begin{array}{l}576 \\
\pm 10\end{array}$ & $\begin{array}{l}307 \\
\pm 22\end{array}$ & $\begin{array}{l}42 \\
\pm 6\end{array}$ \\
\hline $\mathrm{KN}$ & - & - & $\begin{array}{c}32 \\
\pm 12\end{array}$ & $\begin{array}{l}106 \\
\pm 16\end{array}$ & $\begin{array}{c}63 \\
\pm 18\end{array}$ & $\begin{array}{l}19 \\
\pm 3\end{array}$ & $\begin{array}{c}71 \\
\pm 12\end{array}$ & $\begin{array}{l}62 \\
\pm 8\end{array}$ & $\begin{array}{c}37 \\
\pm 13\end{array}$ & $\begin{array}{c}128 \\
\pm 5\end{array}$ & $\begin{array}{c}101 \\
\pm 6\end{array}$ & $\begin{array}{l}41 \\
\pm 1\end{array}$ \\
\hline $\mathrm{NH}_{4}-\mathrm{N}$ & - & - & - & $\begin{array}{l}67 \\
\pm 9\end{array}$ & $\begin{array}{l}48 \\
\pm 5\end{array}$ & $\begin{array}{l}15 \\
\pm 2\end{array}$ & $\begin{array}{c}49 \\
\pm 11\end{array}$ & $\begin{array}{l}42 \\
\pm 4\end{array}$ & $\begin{array}{c}29 \\
\pm 10\end{array}$ & $\begin{array}{l}78 \\
\pm 8\end{array}$ & $\begin{array}{l}70 \\
\pm 5\end{array}$ & $\begin{array}{c}33 \\
\pm 10\end{array}$ \\
\hline $\mathrm{NO}_{3}-\mathrm{N}$ & - & - & - & $\begin{array}{l}0.5 \\
\pm 0\end{array}$ & $\begin{array}{l}4.4 \\
\pm 5\end{array}$ & $\begin{array}{l}23 \\
\pm 9\end{array}$ & $\begin{array}{l}0.5 \\
\pm 0\end{array}$ & $\begin{array}{l}1.9 \\
\pm 2\end{array}$ & $\begin{array}{c}18 \\
\pm 21\end{array}$ & $\begin{array}{l}0.5 \\
\pm 0\end{array}$ & $\begin{array}{l}0.5 \\
\pm 0\end{array}$ & $\begin{array}{l}15 \\
\pm 1\end{array}$ \\
\hline Removal rate $(\%)$ & local & & lobal & local & & obal & local & & lobal & loca & & lobal \\
\hline SS & $76 \pm 22$ & & $8 \pm 15$ & $94 \pm$ & & $6 \pm 1$ & $84 \pm 7$ & & $7 \pm 3$ & $90 \pm$ & & $5 \pm 1$ \\
\hline COD & $74 \pm 13$ & & $39 \pm 7$ & $89 \pm$ & & $2 \pm 1$ & $80 \pm 4$ & & $2 \pm 4$ & $83 \pm$ & & $0 \pm 1$ \\
\hline $\mathrm{BOD}_{5}$ & $84 \pm 11$ & & $3 \pm 5$ & 93 & & 96 & 86 & & 90 & $86 \pm$ & & $3 \pm 1$ \\
\hline $\mathrm{KN}$ & - & & - & $67 \pm 1$ & & $2 \pm 1$ & $40 \pm 18$ & & $6 \pm 23$ & $59 \pm$ & & $8 \pm 2$ \\
\hline $\mathrm{NH}_{4}-\mathrm{N}$ & - & & - & $58 \pm 2$ & & $7 \pm 1$ & $30 \pm 20$ & & $7 \pm 32$ & $53 \pm$ & & $7 \pm 5$ \\
\hline
\end{tabular}



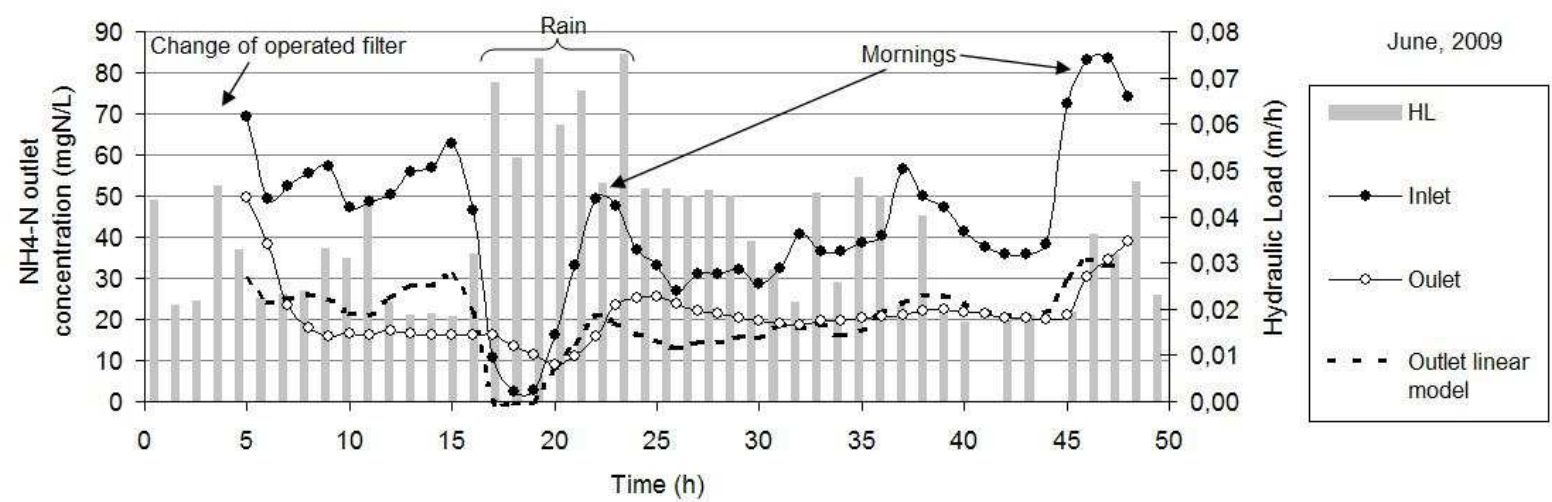

Fig. 1. $\mathrm{NH}_{4}-\mathrm{N}$ concentration during two successive 24 -h flow composite samples, $100 \%$ RFR (June, 2009)

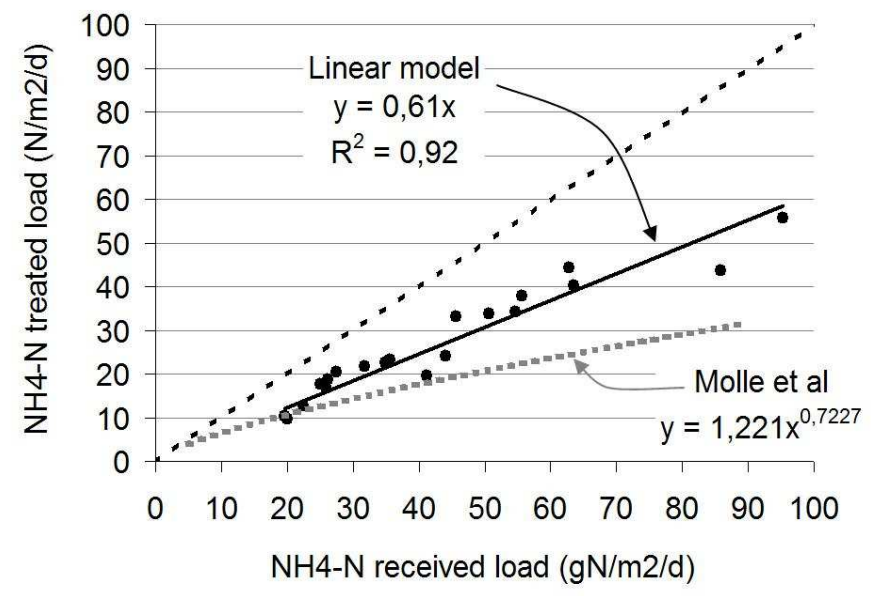

Fig. 2. Treated $\mathrm{NH}_{4}-\mathrm{N}, 100 \% \mathrm{RFR}$ and $\mathrm{C}_{\text {in }}>40 \mathrm{mgNH}_{4}-\mathrm{N}^{-L^{-1}}$ (June, 2009)
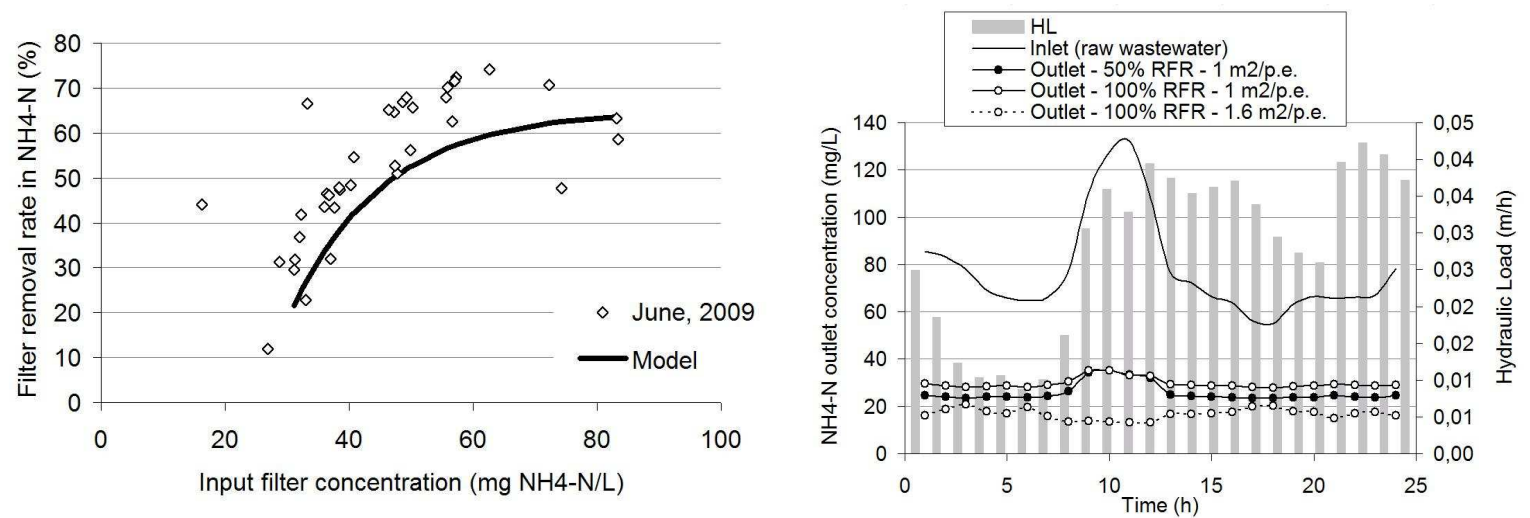

Fig. 3. 3a), Schedule nitrification yields linked to $\mathrm{NH}_{4}-\mathrm{N}$ inlet concentrations and, 3b), Evolution of the theoretical outlet $\mathrm{NH}_{4}-\mathrm{N}$ concentrations according to different design and RFR conditions 